\title{
Parotid Gland with Double Duct: An Anatomic Variation Description
}

\author{
Glándula Parótida con Doble Conducto: Descripción de una Variación Anatómica
}

\section{*,**Atson Carlos de Souza Fernandes; *Rafael Guimarães Lima; "Marcelle Alvarez Rossi \& *** Márcio Cajazeira Aguiar}

FERNANDES, A. C. S.; LIMA, G. R.; ROSSI, A. M. \& AGUIAR, C. M. Parotid gland with double duct: An anatomic variation description. Int. J. Morphol., 27(1):129-132, 2009.

SUMMARY: The parotid is the largest salivary gland in humans producing an essentially serous secretion, which normally reaches the oral cavity through a sole duct (the parotid duct) after the latter making its way through the buccinator muscle to reach the mucosa lining the mouth at the level of the cheek. The present study reports on a rare case of double parotid duct found during the dissection the right side of the face of a cadaver of a 46-year-old male individual. The superior (D1) and inferior (D2) ducts were 26.49 $\mathrm{mm}$ and $37.25 \mathrm{~mm}$ long, respectively. Based on the diameter of both ducts (D1 and D2) taken in the posterior (3.05 mm and $2.84 \mathrm{~mm}$, respectively) and mid ( $2.84 \mathrm{~mm}$ and $2.68 \mathrm{~mm}$, respectively) thirds, as well as on the histological findings, both ducts were considered to be main parotid ducts. These two ducts merged at the level of the anterior third forming one sole opening into the oral cavity. The data hereby reported are relevant to the various clinical and surgical procedures involving the parotid gland.

KEY WORDS: Parotid gland; Parotid duct; Double duct; Anatomical variation; Stensen duct.

\section{INTRODUCTION}

The parotid gland (PG), the largest salivary gland, is the located anteriorly and inferiorly in the external acoustic meatus, partially covering the ramus of the mandible and the masseter muscle (Stranding, 2005). The saliva produced by the parotid gland is mainly serous with a high content of amylase and immunoglobulin $\mathrm{A}$.

The embryonic development of parotid gland is well established. The parotid gland is formed by the proliferating ectoderm of the primitive oral cavity, which invaginates into the adjacent mesenchyma during the sixth week of pre-natal development. Such invagination gives rise to several epithelial sprouts that proliferate and migrate posteriorly in a chain of cells that bend over in order to form ducts by the time the tenth week of gestation is reached. The posterior ends of each epithelial structure differentiate to form acini, which start their secretory function around the eighteenth gestational week (Moore \& Persaud, 2002).

The ducts directly linked to the secretory tissue have smaller diameter and are lined with a single layer of cubic epithelial cells. These ducts merge to form larger and larger ones until excretory ducts are formed having a stratified layer of cuboid epithelial cells, followed by larger ducts lined with layers of cilindridal epithelial cell, which finally merge to form a single main duct, the Stensen's duct. This is formed by smaller ducts lying near the posterior margin of the ramus of the mandible, and measures about $5 \mathrm{~cm}$ (Williams et al., 1995; Peterson et al., 2002).

The Stensen's duct, then, crosses horizontally off the anterior margin of the ramus of the mandible, passes laterally to the masseter muscle, goes around its anterior margin and through the buccinator muscle to end up into the oral cavity (Jébéjian \& Hajenlian, 1993; Gleeson, 1997). Its diameter measure from 3 to $4 \mathrm{~mm}$ showing marked reduction approaching the oral cavity (Williams et al.; Zenk et al., 1998).

Along the course of the Stensen's duct lies an accessory parotid gland (Rahmathulla, 1973; Peterson et al.), laterally to the masseter muscle between the parotid duct

\footnotetext{
* Department of Anatomy, School of Dentistry, Bahiana Foundation for Development of the Sciences, Salvador, BA, Brazil.

** Department of Life Sciences, State University of Bahia, Salvador, BA, Brazil.

${ }^{* * *}$ Department of Biomorphology, Institute of Health Sciences, Federal University of Bahia, Salvador, BA, Brazil.
} 
and the zigomatic arch. Small ducts originating in this accessory gland empty into the parotid duct (Moore \& Dalley, 2005).

The proper knowledge of the normal topographic anatomy and variations of the Stensen's duct is highly relevant to clinical procedures including the analysis of radiographic images (Samanta et al., 2007) and computerized tomographic scans used in sialography (Bahadir et al., 2004), as well as for duct endoscopy, lithotripsy and trans-ductal facial nerve stimulation in the early stage of facial palsy (Thibault et al., 1993; Zenk et al.; Moore \& Dalley).

The present study reports on a rare case of anatomic variation of the parotid duct, which seems to be of some relevance to several diagnostic procedures and surgical interventions on a daily clinic practice.

\section{CASE REPORT}

During a routine cadaver dissection in the anatomy laboratory performed as part of the instruction of students taking the odontology program, the occurrence of a double parotid duct was observed in the right aspect of the face of a 46-year-old, white, male, Latin-American subject fixed with $10 \%$ formalin, who died of natural causes. The body region containing the ducts was carefully dissected and notes on the neighboring anatomic features were taken, followed by measurements and photo taking (Fig.1).

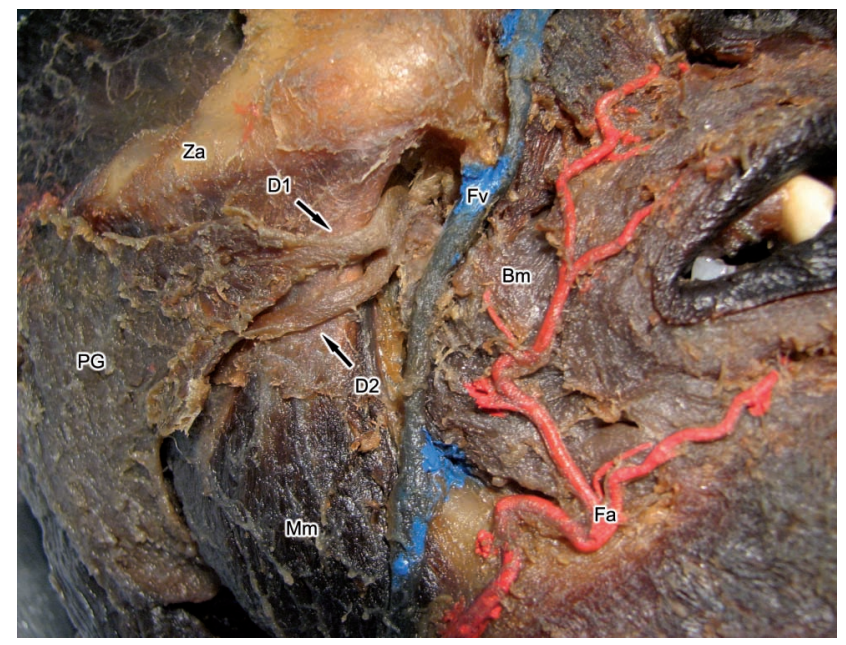

Fig.1. Photograph of dissected specimen in the right cheek showing: D1 and D2. Double parotid duct; PG. Main parotid gland; Za. Zigomatic arch; Bm. Buccinator muscle; Mm. Masseter muscle; Fv. Facial vein; Fa. Facial artery.

As afore said, two ducts were observed at dissection, a superior (D1) and an inferior (D2) duct. The measurement of these ducts were carried out using a digital caliper (Mitutoyo, model Mycal Absolute, with $0.01 \mathrm{~mm}$ resolution). The anterior border of the PG was taken as reference to determine the length of D1 and D2 until the point where they merged $-26.49 \mathrm{~mm}$ and $37.25 \mathrm{~mm}$, respectively. Both ducts were divided into thirds and the diameter of each determined in the proximal, or the most posterior $-3.05 \mathrm{~mm}$ and 2.84 $\mathrm{mm}$, respectively - and middle $-3.31 \mathrm{~mm}$ and $2.68 \mathrm{~mm}$, respectively - thirds.
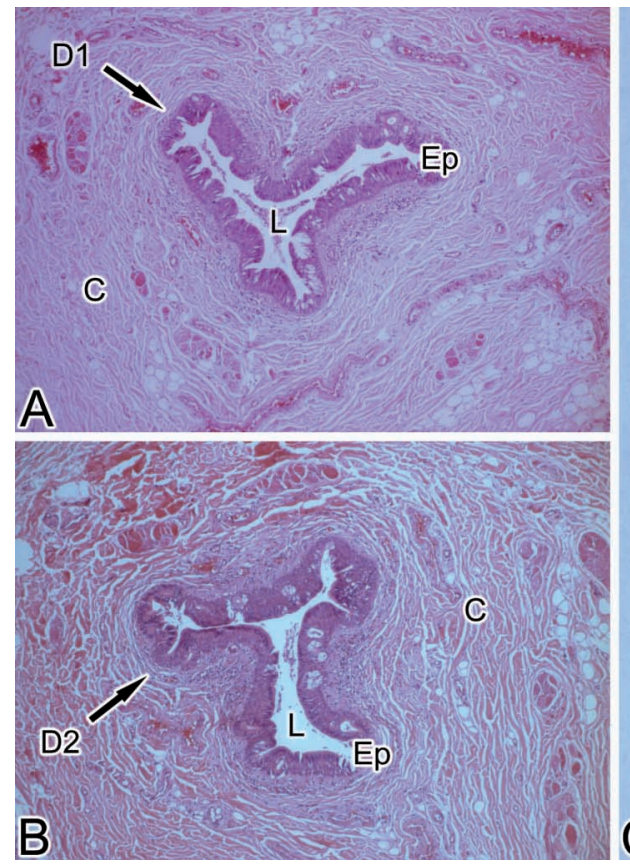

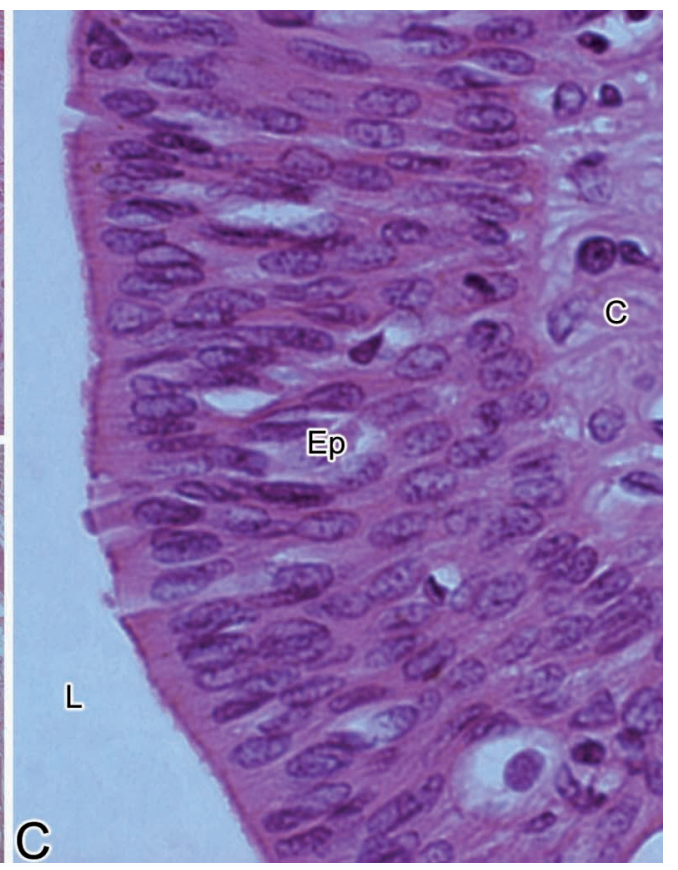

Fig.2. Light micrographs showing D1 and D2 parotid ducts and characteristics of its epithelial covering. In A and B, lumen can be seen in the center of the D1 and D2 ducts (arrows). In C, a higher magnification view of the D2 duct displayed epithelial covering constituted by stratified columnar epithelium. L. lumen; Ep. epithelium; C. connective tissue. 
Both ducts merged at $3.35 \mathrm{~mm}$ just before perforating the buccinator muscle, thus originating a sole parotid papilla containing a sole opening to the oral cavity. It was also determined that both ducts are apart to a maximum of $3.6 \mathrm{~mm}$.

At the dissection of the opposite aspect of the face, only one parotid duct was found. Its diameter in the proximal and middle thirds measured $3.50 \mathrm{~mm}$ and $3.46 \mathrm{~mm}$, respectively.

The histological examination of D1 and D2 after hematoxylin and eosin dying showed a well-defined duct lumen lined by a stratified columnar epithelium in both ducts (Figs. 2A, 2B and 2C).

\section{DISCUSSION}

The anatomy of the parotid duct (Stensen's duct) is highly important for those professionals performing diagnostic and surgical procedures involving such an anatomic structure (Zenk et al.; Bahadir et al.; Samanta et al.).

Aktan et al. (2001) reported a case of double parotid duct in the right aspect of the face in a 63-year-old male human subject. The authors considered each of these ducts as extensions of the intra-parotid ascending and descending ducts, which did not merge inside the PG as it occurs normally. We also report a case of double parotid duct in the right aspect of the face. However we were not able to determine the features of each branch of this double duct (D1 and D2) inside the PG.

The literature report the parotid duct as running below the zygomatic arch and laterally to the masseter muscle until it reaches the anterior border of this muscle, where it makes a medial turn to go through the buccinator muscle to end as the parotid papilla on the inner surface of the oral cavity at the level of the maxillary first to second molar crown (Jébéjian \& Hajenlian; Gleeson; Moore \& Dalley). The course of the double parotid duct presently reported follows the normal anatomical pattern with both branches running parallel to merge $3.35 \mathrm{~mm}$ just before getting into the buccinator muscle, thus emerging as a sole duct to end as a sole opening on the mucosa of the oral cavity. Aktan et al. also reported the merge of both branches before reaching the buccinator muscle but as occurring further before at a distance of $7 \mathrm{~mm}$. Gaur et al. (1994) reported on a case of three ducts leaving the left submandibular gland in a male adult Indian cadaver, each of which ran independently and ended as an independent opening in the mouth floor. Mori et al. (1986) also reported on a sialographic examination of a 73-year-old male Japanese patient showing 2 ducts running out of the right submandibular gland, which merged just before forming a sole opening in the sublingual papilla.
The difference in diameter measurements between the superior and inferior ducts presently reported - D1 and D2, respectively - was minimal, thus leading to the assumption that both should be considered as main ducts. Furthermore, the diameter measures taken in the proximal and middle thirds of $\mathrm{D} 1-3.05 \mathrm{~mm}$ and $3.31 \mathrm{~mm}$, respectively - and D2 $-2.84 \mathrm{~mm}$ and $2.68 \mathrm{~mm}$, respectively - agree with the measures reported for the parotid duct by Williams et al. and Zenk et al. Despite Aktan et al. not reporting on the diameter of their double Stensen's duct, they described both branches as main ones. In the case of more than one duct leaving the right submandibular gland, Mori et al., did not make any distinction between them, whereas Gaur et al., described the one running highest as the largest and considered the other two as accessory ducts.

The length of the ducts D1 and D2 presently reported $-26.49 \mathrm{~mm}$ and $37.25 \mathrm{~mm}$, respectively (Fig.1) - is the only main divergence with the study by Aktan et al., who reported a sole measurement $-55 \mathrm{~mm}$. However such discrepancy is likely to reflect the different biotypes in which the same variation is reported.

Aktan et al., stated in their report not knowing any other detailed study on a case of double parotid duct. In fact, our bibliographic review rendered only the case report by these authors. Others speculate or make reference only without being specific as to their sources of information. Peterson et al. suggested that the drainage of the salivary secretion performed by Stensen's duct may be helped by possibly existing accessory parotid ducts. Bailey (1971) stated that the literature shows the occurrence of double parotid duct in $7 \%$ of population.

The aim of the histological study was to determine the existence of a lumen, and if so, to determine characteristics of its likely epithelial lining in both parotid ducts presently reported. The histological analysis confirmed the occurrence of a wide lumen in both ducts as reported by Aktan et al. and Gaur et al. Furthermore, both ducts showed an epithelial lining similar in structure to that normally found in the most anterior portion of the parotid duct suggesting that both should be considered as main ducts.

Embryological studies show that during the formation of the PG, epithelia sprouts from the ectoderm reach out back towards the ear. The branches originated from these sprouts later will form communicating ducts that normally give rise to a sole parotid duct connecting the PG to the oral cavity (Williams et al.; Moore \& Persaud). Based on both the embryological origin of the PG and the evidences from the histological analysis, we speculate that the two distinct ducts D1 and D2 developed from the early formation of two epithelial sprouts and the invagination of the ectoderm which 
later originated a complex of ducts and acini resulting in the formation of the PG bearing a double parotid duct.

Although the presence of a second parotid duct does not necessarily reflect on any damage to the drainage of the salivary secretion, being unaware of such variation can bring about either any undesirable event during surgical procedures or inaccuracy in diagnostic tests regarding the PG or the imaging of its neighboring anatomical structures. We recommend that surgeons and radiologists performing any procedures in the region of the face bear in mind the potential anatomical variation hereby reported.

FERNANDES, A. C. S.; LIMA, G. R.; ROSSI, A. M. \& AGUIAR, C. M. Glándula parótida con doble conducto: descripción de una variación anatómica. Int. J. Morphol., 27(1):129-132, 2009.

RESUMEN: La parótida es la glándula salival más grande presente en el hombre y su producto de secreción, básicamente seroso, es normalmente dirigido hasta la cavidad oral, a través de un único canal parotídeo que, luego de perforar el músculo buccinador, desemboca en la mucosa de la mejilla. Este trabajo muestra un caso raro de doble canal parotídeo hallado durante la diseccción de un cadáver de sexo masculino, de 46 años de edad, en el lado derecho del rostro. Los canales superior (D1) e inferior (D2), presentaron una longitud de 26,49 mm y 37,25 mm, respectivamente. En base a los diámetros presentados por los canales en los tercios posterior (D1 3,05mm; D2 2,84 mm) y medio (D1 2,84mm; D2 2,68 mm) y de acuerdo con los hallazgos histológicos, ambos fueron considerados principales. En el tercio más anterior los canales se fusionaron, presentando una única apertura en la cavidad oral. Las informaciones presentadas en este documento son relevantes para diferentes procedimientos clínicos y quirúrgicos que tengan relación con la glándula parótida.

PALABRAS CLAVE: Glándula parótida; Canal parotídeo; Doble canal; Variaciones; Conducto de Stensen.

\section{REFERENCES}

Aktan, Z. A.; Bilge, O.; Pinar, Y. A. \& Ikiz, A. O. Duplication of the parotid duct: a previously unreported anomaly. Surg. Radiol. Anat., 23(5):353-4, 2001.

Bahadir, O.; Caylan, R.; Bektas, D. \& Korkmaz, O. Sialolithiasis of an accessory parotid gland. Ann. Otol. Rhinol. Laryngol., 113(1):52-4, 2004.

Bailey, L. Short practice of surgery. $15^{\text {th }}$ London, Lewis, 1971. p. 533.

Gaur, U.; Choudhry, R.; Anand, C. \& Choudhry, S. Submandibular gland with multiple ducts. Surg. Radiol. Anat. 16(4):439-40, 1994.

Gleeson, M. Scott-Brown's Otolaryngology. $6^{\text {th }}$. London, Butterworth-Heinemann, Bath, 1997. V.1. p.3.

Jébéjian, R. \& Hajenlian, G. A simple setting for continuous irrigation in Charleux surgery for dry eye. Rev. Int. Trach. Pathol. Ocul. Trop. Subtrop. Sante Publique, 70:217-23, 1993.

Moore, K. L. \& Persaud, T. V. N. The Developing Human: Clinically Oriented Embryology. $7^{\text {th }}$ Philadelphia, Saunders, 2002.

Moore, K. L. \& Dalley, A. F. Clinically Oriented Anatomy. $5^{\text {th }}$ Toronto, Lippincott Williams \& Wilkins, 2005.

Mori, S.; Wada, T.; Harada, Y. \& Toyoshima, S. Accessory duct in the submandibular gland. Oral Surg. Oral Med. Oral Pathol. 62(5):607-8, 1986.

Peterson, L. J.; Ellis, E.; Hupp, J. R. \& Tucker, M. R. Contemporary Oral and Maxillofacial Surgery. $4^{\text {th }}$ St. Louis, USA, Mosby, 2002.
Rahmathulla, M. A rare case of accessory duct in sub-mandibular sialography. J. Indian. Dent. Assoc., 45(11):563-4, 1973.

Samanta, P. P.; Rana, K. K.; Khan, R. Q. \& Das, S. An unusually located human accessory parotid glanda. A case report. Braz. J. morphol. Sci. 24(1):53-4, 2007.

Standring, S. Gray`s Anatomy. The anatomical basis of clinical practice. $3^{\text {rd }}$ Edinburgh, Elsevier Churchill Livingstone, 2005.

Thibault, F.; Halimi, P.; Bely, N.; Chevallier, J. M.; Bonfils, P.; Lellouch-Tubiana, A. \& Frija, G. Internal architecture of the parotid gland at MR imaging facial nerve or ductal system? Radiology, 188(3):701-5, 1993.

Williams, P. L.; Bannister, L. H.; Berry, M. M.; Collins, P.; Dyson, M.; Dussek, J. E. \& Ferguson, M. V. J. Gray`s Anatomy. $38^{\text {th }}$ ed. New York, Churchill Livingstone, 1995.

Zenk, J.; Hosemann, W. G.; \& Iro, H. Diameters of the main excretory ducts of the adult human submandibular and parotid gland. Oral Surg. Oral Med. Oral Pathol. Oral Radiol. Endodotol., 85(5):576-80, 1998.

\section{Correspondence to:}

Prof. Dr. Atson Carlos de Souza Fernandes

Departamento de Ciências da Vida - DCV Campus-I

Universidade do Estado da Bahia - UNEB

Rua Silveira Martins, 2555, Cabula

Salvador - Bahia

BRASIL

E-mail: atson@uneb.br; atsonfernandes@yahoo.com.br

Received: 13-05-2008

Accepted: 28-10-2008 